\title{
Effect of Teachers Training Workshop Outcomes on Real Classroom Situations of Undergraduate Medical Students
}

\author{
Baral $N,{ }^{1}$ Nepal AK, ${ }^{1}$ Paudel $B H,{ }^{2}$ Lamsal $\mathrm{M}^{1}$
}

${ }^{1}$ Department of Biochemistry

${ }^{2}$ Department of Basic and Clinical Physiology

B.P. Koirala Institute of Health Sciences

Dharan, Nepal,

\section{Corresponding Author}

Nirmal Baral

Department of Biochemistry

B.P. Koirala Institute of Health Sciences

Dharan, Nepal

E-mail: nirmalbaral@hotmail.com

\section{Citation}

Baral N, Nepal AK, Paudel BH, Lamsal M. Effect of Teachers Training Workshop Outcomes on Real Classroom Situations of Undergraduate Medical Students. Kathmandu Univ Med J 2015;50(2):162-6.

\section{ABSTRACT}

\section{Background}

Faculty development by conducting regular training, workshops and research related to medical education has been a key feature to upgrade quality of medical education.

\section{Objective}

The aim of this study was to explore responses of the health science teachers, students and peers after the workshop after providing training on student assessment tools and teaching-learning methods.

\section{Method}

Two teacher-training workshops were conducted to the faculty members of B.P. Koirala Institute of Health Sciences from the departments of basic, clinical and allied sciences in Oct. 2010 and Jan. 2011. Qualitative questionnaire based study was conducted, and the questions were validated before the study by expert peer review process. The effect of the training workshop in real classroom outcomes was assessed incorporating student's feedback, evaluation by peers and the self-evaluation by the teacher trainees.

\section{Result}

Pre-test and post-test scores of the participating teachers, before and after the workshop were 62.53 and 71.17 respectively. Among the participants $90.3 \%$ teachers expressed enhanced in their role as a teacher for medical undergraduates after the workshop.

\section{Conclusion}

In present study, the faculty members showed accrued interest to participate in teacher's training workshops. The peer evaluation of teacher's performance in their real classroom situations were rated higher than evaluation by the students. Therefore, such training workshops will have a greater impact on the ability of teachers in effective teaching in real classroom situations.

\section{KEY WORDS}

Medical education, Nepal, teachers training. 


\section{INTRODUCTION}

Advanced teaching in health professional education has been implemented in many American Medical schools since 1950s. ${ }^{1}$ Emphasis has been given to developing both educational skills and the health profession specialty skills. However, educational skills are lagging behind, gaining less focus than the latter skills. ${ }^{2}$ Peer observed teaching provides an opportunity to respond to their peers in teaching learning practice, which improves and accounts for the quality teaching in higher education. ${ }^{3}$

Ramsden, 2003 has described that there has been no single right answer to the problem of improving the quality of University teaching. ${ }^{4}$ Shortland, 2004 has stated that the choice of inappropriate methodology may lead to de-motivating feedback, which may present a dilemma in observation practice. ${ }^{3,5}$ Teacher's training workshop programs have emerged as a more depth and comprehensive mechanisms for strengthening instructional skills, formulating assessment techniques and use of audio visuals and recent technology among the faculty members. ${ }^{6-8}$ B.P. Koirala Institute of Health Sciences (BPKIHS), Dharan, Nepal, has an integrated and organ-system based Undergraduate medical curriculum. Structured Interactive Session (SIS), problem-based learning $(\mathrm{PBL})$, practical demonstration, seminars as well as clinical case discussions, bed-side teaching and field-based learning have been implemented in BPKIHS. ${ }^{9}$

Training of health professionals in medical education by enhancing their instructional skills, lecture plan, communication skills, use of audio-visual aids, improving quality medical education by faculty development, and to develop competent health workforce and researchers with innovative health requirements are the key objectives of the teachers training programs. ${ }^{10}$ However, these trainings only focus to train the teachers but their performance in real classroom situations, and feedback from peer and students in classroom after the training have rarely been studied. Here we present a study, which was conducted to assess the outcomes of a teachers training workshops aimed at orienting faculty members with principles of evaluations, steps and characteristics of evaluation tools and formulation of commonly practiced assessment methods in building capacity of a teachers, in real classroom situations. The main objective of this study was to assess: i) the impact of teachers training to the teachers through personal feedback, ii) evaluation from peer feedback after teachers training in real classroom situation and, iii) evaluation from students feedback in real classroom situations.

\section{METHODS}

The present study was conducted in the Department of Health Professions Education, BPKIHS, Dharan, Nepal. Two teacher-training workshops, each of two and half days duration were conducted in Oct. 2010 and Jan. 2011 respectively. Both teachers-training workshops included a refresher training having nine hours of interactive teaching sessions, six hours of group exercises, daily evaluations and three hours of presentation by participants. Fourty entry-level faculty members were invited for the training, among which 31 had participated, with a response rate of $77.5 \%$. Qualitative questionnaire based study was performed to assess the perception of participants towards the workshop, and the questions were validated before the study by expert peer review process. The effect of the workshop training on teachers' performance in classroom outcomes was assessed by incorporating student feedback, evaluation by peers and the self-evaluation by the teachers. The trainees were requested to provide their feedback regarding the program evaluation during the workshop and the refresher training. The student response to real classroom outcomes, peer-evaluation and self-evaluation towards teachers' performance were studied after three months of the completion of the refresher trainings. The responses measured in 5-point likert scale were reduced to 3-point by merging strongly agree and agree as "agree" and strongly disagree and disagree as "disagree". The teachers, the students and the peers were notified about the study, and appropriate consents were taken. Due permissions was obtained from Institutional Ethical Review Board, BPKIHS to undertake the study. Data were entered in MS Excel 2007, and Statistical Package for Social Sciences (SPSS) 16.0 (SPSS Inc., USA) was used to calculate descriptive and inferential statistics. The qualitative data were expressed in frequency and percentages.

\section{RESULTS}

The participants $(\mathrm{N}=31)$ in both the workshops responded to the questionnaire during the pre and post-sessions. The teachers participating in the training were from basic sciences $(n=22)$, clinical sciences $(n=5)$ and allied health sciences $(n=4)$. Pre-test and post-test scores of the participating teachers on their knowledge on different aspects of medical education, before and after the workshop were 62.53 and 71.17 , respectively. Among the participating teachers $90.3 \%$ teachers said that they felt enhanced in their role as a teacher for medical undergraduates after the workshop. Also, 90.6\% of the teachers reported that the workshop had helped them to learn skills in developing short answer questions (SAQ), multiple-choice questions (MCQ), problem based questions (PBQ), objective structured practical examination (OSPE) and objective structured clinical examination (OSCE) (Table 1). Lecture delivery skills of the teachers after the workshop as responded by peers Vs students were as follows: i) specifies purpose at introduction (92.3\%) Vs (71\%), ii) changes pace of the lecture periodically $(52.8 \%)$ Vs (45.8\%), iii) summarize the important points $(92.3 \%)$ Vs $(66.4 \%)$ and, iv) can be determined that the learner objectives are met (76.9\%) Vs 53.8\% (Tables $2 \& 3$ ). 
Table 1. Responses from the participant teachers after the workshop in a 3 point liker scale

\begin{tabular}{|c|c|c|c|c|}
\hline & \multirow[t]{2}{*}{ Topics } & \multicolumn{3}{|c|}{ Response } \\
\hline & & $\begin{array}{l}\text { Disagree } \\
\mathrm{N}(\%)\end{array}$ & $\begin{array}{c}\text { Neutral } \\
\mathrm{N}(\%)\end{array}$ & $\begin{array}{l}\text { Agree } \\
\mathrm{N}(\%)\end{array}$ \\
\hline 1 & $\begin{array}{l}\text { I feel enhanced in my role as a } \\
\text { teacher for medical undergraduates } \\
\text { after the workshop }\end{array}$ & - & $3(10)$ & $28(90)$ \\
\hline 2 & $\begin{array}{l}\text { The workshop has helped me to } \\
\text { learn skills in developing SAQ/MCQ/ } \\
\text { PBQ/OSPE/OSCE }\end{array}$ & - & $1(3)$ & $30(97)$ \\
\hline 3 & $\begin{array}{l}\text { I recommend this training to other } \\
\text { colleagues }\end{array}$ & - & - & $31(100)$ \\
\hline 4 & $\begin{array}{l}\text { I am interested in taking the similar } \\
\text { training in near future }\end{array}$ & - & $4(13)$ & $27(87)$ \\
\hline 5 & $\begin{array}{l}\text { Such a workshop should be incorpo- } \\
\text { rated in the Postgraduate program }\end{array}$ & - & $9(29)$ & $22(71)$ \\
\hline 6 & $\begin{array}{l}\text { The provided instruction in the } \\
\text { workshop is relevant for my teach- } \\
\text { ing responsibilities }\end{array}$ & - & $7(22)$ & $24(78)$ \\
\hline \multirow[t]{7}{*}{7} & $\begin{array}{l}\text { Changes in teaching practice after } \\
\text { attending the workshop }\end{array}$ & & & \\
\hline & i. I plan lesson better & - & $2(7)$ & $14.5(93)$ \\
\hline & $\begin{array}{l}\text { ii. I have improved setting of objec- } \\
\text { tives }\end{array}$ & - & $2(7)$ & $14.5(93)$ \\
\hline & iii. I interact better with students & - & $3(9.7)$ & 14(90.3) \\
\hline & $\begin{array}{l}\text { iv. I have improved using of audio- } \\
\text { visual, teaching aids }\end{array}$ & $1(3)$ & $5(16)$ & $25(80)$ \\
\hline & $\begin{array}{l}\text { v. I use various teaching learning } \\
\text { methods -(SGD, Tutorial, PBL/CBL) }\end{array}$ & - & $12(39)$ & $19(61)$ \\
\hline & $\begin{array}{l}\text { vi. I feel that I deliver lecture more } \\
\text { effectively }\end{array}$ & - & $6(19)$ & $25(81)$ \\
\hline
\end{tabular}

Table 2. Evaluation of the teachers by the peers in real classroom situations in a three-point liker scale

\begin{tabular}{|c|c|c|c|c|}
\hline & \multirow[t]{2}{*}{ Topics } & \multicolumn{3}{|c|}{ Response } \\
\hline & & $\begin{array}{l}\text { Disagree } \\
\mathrm{N}(\%)\end{array}$ & $\begin{array}{c}\text { Neutral } \\
\mathrm{N}(\%)\end{array}$ & $\begin{array}{l}\text { Agree } \\
\mathrm{N}(\%)\end{array}$ \\
\hline \multirow[t]{5}{*}{1} & $\begin{array}{l}\text { Effective Lecture presentation and } \\
\text { delivery skills' }\end{array}$ & & & \\
\hline & $\begin{array}{l}\text { i. Specifies purpose of the lecture in } \\
\text { introduction: }\end{array}$ & - & $1(7.7)$ & $12(92.3)$ \\
\hline & $\begin{array}{l}\text { ii. Changes pace of lecture periodi- } \\
\text { cally }\end{array}$ & - & $6(46.2)$ & $7(53.8)$ \\
\hline & $\begin{array}{l}\text { iii. Summarizes most important } \\
\text { points or ideas of the lecture }\end{array}$ & - & $1(7.7)$ & $12(92.3)$ \\
\hline & $\begin{array}{l}\text { iv. Can be determined that the } \\
\text { learner objectives are met }\end{array}$ & - & $3(23.1)$ & $10(76.9)$ \\
\hline 2 & $\begin{array}{l}\text { Uses audio-visual aids to enhance } \\
\text { understanding of the subject matter }\end{array}$ & $1(7.7)$ & - & $12(92.3)$ \\
\hline \multirow[t]{3}{*}{3} & $\begin{array}{l}\text { Skills in use of voice and body } \\
\text { language }\end{array}$ & & & \\
\hline & $\begin{array}{l}\text { i. Speak at a suitable volume for the } \\
\text { audience }\end{array}$ & - & $2(15.4)$ & $11(84.6)$ \\
\hline & $\begin{array}{l}\text { ii. Varies rate, pitch, force or tone for } \\
\text { emphasis }\end{array}$ & $2(15.4)$ & $3(23.1)$ & $8(61.5)$ \\
\hline 4 & Effective time management skills & - & $8(47)$ & $9(53)$ \\
\hline 5 & $\begin{array}{l}\text { Small group discussions within the } \\
\text { lecture }\end{array}$ & $6(46.2)$ & $6(46.2)$ & $1(7.6)$ \\
\hline 6 & $\begin{array}{l}\text { Teacher's way of teaching has } \\
\text { improved after workshop }\end{array}$ & $1(7.7)$ & $2(15.4)$ & 10(76.9) \\
\hline 7 & $\begin{array}{l}\text { Teacher has enhanced the way of } \\
\text { evaluation using appropriate tools }\end{array}$ & $1(7.7)$ & $2(15.4)$ & $10(76.9)$ \\
\hline
\end{tabular}

Table 3. Evaluation of the teachers by students in real classroom situation in a three-point liker scale

\begin{tabular}{|c|c|c|c|c|}
\hline & \multirow[t]{2}{*}{ Characteristics Topics } & \multicolumn{3}{|c|}{ Response } \\
\hline & & $\begin{array}{l}\text { Disagree } \\
\mathrm{N}(\%)\end{array}$ & $\begin{array}{c}\text { Neutral } \\
\mathrm{N}(\%)\end{array}$ & Agree $\mathrm{N}(\%)$ \\
\hline \multirow[t]{5}{*}{1} & $\begin{array}{l}\text { Effective Lecture presenta- } \\
\text { tion and delivery skills }\end{array}$ & & & \\
\hline & $\begin{array}{l}\text { i. Specifies purpose of the } \\
\text { lecture in introduction: }\end{array}$ & $25(9.5)$ & $51(19.5)$ & $186(71)$ \\
\hline & $\begin{array}{l}\text { ii. Changes pace of } \\
\text { lecture periodically }\end{array}$ & $67(25.6)$ & $75(28.6)$ & $120(45.8)$ \\
\hline & $\begin{array}{l}\text { iii. Summarizes most impor- } \\
\text { tant points or ideas of the } \\
\text { lecture }\end{array}$ & $30(11.5)$ & $58(22.1)$ & $174(66.4)$ \\
\hline & $\begin{array}{l}\text { iv. Can be determined that } \\
\text { the learner } \\
\text { objectives are met }\end{array}$ & $41(15.6)$ & $80(30.5)$ & $141(53.8)$ \\
\hline 2 & $\begin{array}{l}\text { Uses audio-visual aids to en- } \\
\text { hance understanding of the } \\
\text { subject matter }\end{array}$ & $41(15.6)$ & $70(26.7)$ & $151(57.6)$ \\
\hline \multirow[t]{3}{*}{3} & $\begin{array}{l}\text { Skills in use of voice and } \\
\text { body movements }\end{array}$ & & & \\
\hline & $\begin{array}{l}\text { i. Speak at a suitable } \\
\text { volume for the audience }\end{array}$ & $28(10.7)$ & $52(19.8)$ & $182(69.5)$ \\
\hline & $\begin{array}{l}\text { ii. Varies rate, pitch, force or } \\
\text { tone for emphasis }\end{array}$ & 39(14.9) & $71(27.1)$ & $152(58.0)$ \\
\hline 4 & $\begin{array}{l}\text { Effective time management } \\
\text { skills }\end{array}$ & $57(21.8)$ & $57(21.8)$ & $147(56.1)$ \\
\hline 5 & $\begin{array}{l}\text { The lecture completed in } \\
\text { time and there was enough } \\
\text { time for discussion }\end{array}$ & $80(30.5)$ & $71(27.1)$ & $111(42.4)$ \\
\hline 6 & $\begin{array}{l}\text { I was encouraged to ask } \\
\text { questions }\end{array}$ & $52(19.8)$ & $60(22.9)$ & $149(56.9)$ \\
\hline 7 & $\begin{array}{l}\text { I had an opportunity to } \\
\text { express myself and clarify } \\
\text { doubts }\end{array}$ & $51(19.5)$ & $51(19.5)$ & $160(61.1)$ \\
\hline 8 & $\begin{array}{l}\text { There was proper interac- } \\
\text { tion between the student } \\
\text { and the teacher }\end{array}$ & $72(27.5)$ & $82(31.3)$ & $107(40.8)$ \\
\hline 9 & $\begin{array}{l}\text { Small group discussion was } \\
\text { performed during the lec- } \\
\text { ture }\end{array}$ & $117(44.7)$ & $71(27.1)$ & $74(28.2)$ \\
\hline
\end{tabular}

In open-ended responses the students mentioned that the teachers should make the topics more interesting and easy for every student, and humor and extra-information along with inspirational experience must me shared. The peers reported that the interaction of the students with the teachers has to be encourages with questions in between the lectures, and such type of training should be provided to almost all teachers. The teachers reported that the workshop was useful for them personally and for their colleagues, so the workshops should be conducted in a continued basis for future teachers. The teachers also mentioned that such kind of trainings should be conducted for post-graduate residents who want to pursue a teaching career. 


\section{DISCUSSION}

Medical schools should encourage to emphasize on teaching abilities while recruiting and promoting staff and help the existing staffs to become better teachers. ${ }^{6}$ For the professional development of a teacher, training in entry level is critical and essential for their teaching career development. ${ }^{11}$ The aim of the present study was to evaluate the effectiveness of teachers' training on assessment techniques as assessed by the participants perception by the peers, teachers themselves and by students is the real classroom situation. During evaluation of training and its outcomes the performance of the participants at the beginning and the end should be assessed. The evaluation in this study is more modest and relates to the training course objectives being fulfilled in the immediate shortterm as well as long-term. Clearly, participants did feel more confident at the end of this course. The present study has shown good participation and enthusiasm of teachers to continued medical education through teachers training workshops. The teachers were benefitted by redefining their previous teaching skills and learning new skills. There were incorporation of new techniques such as audiovisuals and skills in preparing SAQ/MCQ/PBQ/OSPE/OSCE in the workshop.

Roermund et al, 2011 reported that teachers were comfortable with a concept of group coach, in the sense of wiser and more experienced colleague and learning to be a teacher was mostly achieved from learning by doing and from the fellow group coach and mentor. ${ }^{12}$ Sullivan et al, 2012 mentioned that teachers described tangible improvement in their teaching practice from the detailed and specific feedback they received from their peers. Teachers mentioned that by peer observed teaching, they were able to make useful changes that led to improvements in overall session, improved audio visual skills, and resulted in more effective teaching experience for the students. ${ }^{3}$ Roermund et al, 2013 in a similar study reported that teachers who had positive feedback from their residents showed positive attitude towards their residents and self-confidence about their teaching abilities. Whereas, teachers with poor results tended to discuss the items and tried to relate the results caused outside themselves and mentioned that the residents didn't understand their approach or attributed the outcomes to the characteristics of residents. ${ }^{13}$

The current workshop has encouraged the teachers to suggest other fellows to attend a similar workshop in near future with a response of $100 \%$. Similarly, teachers felt better skilled in teaching abilities after the workshop. In our study, almost all teachers responded that they planned lesson better, had improved set of objectives, interacted well with students, and had learned to use audio-visuals better after attending the workshop. Learners objective in this study have been men, which may be in part due to the good quality of materials and lectures provided in the workshop, and the lessons learned by the teachers from peer feedback and students' feedback in real classroom situations.

In a previous study conducted in 26 teachers in eastern Nepal, $96 \%$ of the participants reported that there was a better understanding of opportunities and limitation of assessment, and $61 \%$ teachers mentioned that their personal objectives were met. $^{6}$ Similarly, in a 3 days teachers' training conducted in 92 teachers from four medical schools of Nepal, the participants' responsed that the objectives of the workshop were very clear (73.9\%), but $39 \%$ mentioned that the duration was too short. ${ }^{7}$ In a 3 day long PBL training of 25 teachers, the $92 \%$ of the participants mentioned that the training was informative and $88 \%$ teachers reported that they had met personal objective and had learned new techniques about PBL from the workshop. ${ }^{8}$ The above findings are in line with our study, as $78 \%$ of the teachers mentioned that the provided materials were relevant for their teaching responsibilities and $81 \%$ teachers felt that they were able to deliver lecture effectively after the workshop.

The peers evaluated the teachers that almost all the teachers were able to specify the purpose of the lecture in their introduction and summarized the important points at the end of the lecture. Most of the teachers had improved the way of their teaching and they were able to use appropriate tools according to the peers. Almost all the students reported that the lecture presentation and delivery skills of the teachers were improved after the workshop. Most of the students responded that the teachers had improved the quality of voice and the body language, managed time effectively, there was enough time for discussion and the students were encouraged to ask questions. A limitation of this study is that some of the participants' feedback in real classroom situation could not be performed.

\section{CONCLUSION}

The training workshops were informative and the participants learned about teaching learning methods and assessment techniques. Faculty members showed higher interest to participate in future training workshops. The present workshop has enhanced the ability of the teachers in effective teaching in real classroom situations. Responses of peers and students in real classroom situations helped the teachers to improve their teaching abilities and also encouraged them to participate in similar workshop in near future. Such workshop should be conducted on a regular basis to help teachers to understand, implement and prioritize their roles as medical educators. 


\section{ACKNOWLEDGEMENT}

We would like to thank all the faculty members, students and peers for their responses. We want to sincerely thank FAIMER resource faculty members who attended FAIMER fellowship training program during the year of June 2010 to June 2012 held at Regional FAIMER Institute Seth G S Medical College Mumbai, India for their invaluable comments during project submission and final presentation.

\section{REFERENCES}

1. Skeff MK, Stratos GA and Mount JF. Faculty Development in Medicine: A Field in Evolution. Teaching and Teacher Education. 2007;23(3): 280-5.

2. Banda SS. Teaching and Teacher Education for Health Professionals: Perspectives on Quality and Outlook of Health Professionals Education in Zambia. Medical Journal of Zambia. 2008;35(5):70-4.

3. Sullivan BP, Buckle A, Nicky G, Atkinson SH. Peer observation of teaching as a faculty development tool. BMC Medical Education. 2012;12(6):1-6

4. Ramsden P. Learning to teach in higher education. $2^{\text {nd }}$ ed. Oxon: Routledge Faimer; 2003.

5. Shortland S. Observing teaching in HE: A case study of classroom observation within peer observation. Int J Educ Manag. 2004;4(2).

6. Baral N, Gautam A, Lamsal M, Paudel BH, Lal Das BK, Aryal M. Effectiveness of teachers' training in assessment techniques: participants' perception. Kathmandu Univ Med J (KUMJ). 2011 Jul-Sep;9(35):189-92.

7. Baral N, Paudel BH, Das BK, Aryal M, Das BP, Jha N, et al. An evaluation of training of teachers in medical education in four medical schools of Nepal. Nepal Med Coll J. 2007 Sep;9(3):157-61.

8. Baral N, Paudel BH, Das BK, Aryal M, Gautam A, Lamsal M. Preparing tutors for problem-based learning: an experience from B. P. Koirala Institute of Health Sciences, Nepal. Kathmandu Univ Med J (KUMJ). 2010 Jan-Mar;8(29):141-5.

9. Shankar PR, Mishra P and Dubey AK. Modern Medical Education in Nepal. The Clinical Teacher. 2006;3(1):65-8.

10. Srivinas DK, Adkoli BV. Faculty Development in Medical Education in India: The Need of The Day. Al Ameen J Med Sci. 2009;2(1):6-13.

11. Abrahamson S. The dominance of research in staffing of medical schools: time for a change? Lancet. 1991 Jun 29;337(8757):1586-8.

12. van Roermund TC, Tromp F, Scherpbier AJ, Bottema BJ, Bueving HJ. Teachers' ideas versus experts' descriptions of 'the good teacher' in postgraduate medical education: implications for implementation. A qualitative study. BMC Med Educ. 2011;11:42.

13. van Roermund $T$, Schreurs $M L$, Mokkink $H$, Bottema $B$, Scherpbier $A$, van Weel $C$. How do teachers react to feedback from resident evaluations? A qualitative study. BMC Medical Education 2013;13(98). 